Jurnal

\title{
Role of Echocardiography as Supporting Diagnostic Modality in Localized Stanford Type A Aortic Dissection
}

\author{
Haris Munirwan', Amiliana Mardiani Soesanto', Rina Ariani', Taofan', Suko Adiarto' \\ Ismoyo Sunu', Bagus Herlambang ${ }^{2}$, Dicky Aligheri², Retno Dwi Astuti ${ }^{3}$
}

Department of Cardiology and Vascular Medicine, Faculty of Medicine, Universitas Indonesia, National Cardiovascular Center Harapan Kita, Jakarta, Indonesia'. Department of Adult Cardiac and Vascular Surgery, National Cardiovascular Center Harapan Kita, Jakarta, Indonesia ${ }^{2}$. Department of Radiology, National Cardiovascular Center Harapan Kita, Jakarta, Indonesia ${ }^{3}$
Ascending Stanford type A aortic dissection carries a high morbidity and mortality. Proper identification of the proximal origin of the dissection and determination of concomitant aortic valve involvement significantly facilitate surgical repair which may improve survival. ${ }^{2}$ Rapid imaging is necessary for the timely diagnosis of a potentially life-threatening condition. Transthoracic Echocardiography is highly accurate for the detection of acute aortic syndromes especially identify ascending aortic pathology such as type A aortic dissection. ${ }^{3}$ We report the unusual case of 52 -years old male who present atypical presentation of aortic dissection with unclear view of dissection by CT Angiography aorta, and diagnosed as Localized Stanford A Aortic dissection with supported data by echocardiography modality.

(J Kardiol Indones. 2014;35:285-95)

Keywords: transthoracic echocardiography, diagnostic, localized Stanford A aortic dissection 
Jurnal

Kardiologi Indonesia

J Kardiol Indones. 2014;35:285-95

ISSN $0126 / 3773$

\title{
Peran Ekokardiografi sebagai Modalitas Diagnostik Pendukung pada Diseksi Aorta Stanford A Terlokalisir
}

\author{
Haris Munirwan', Amiliana Mardiani Soesanto', Rina Ariani', Taofan', \\ Suko Adiarto', Ismoyo Sunu', Bagus Herlambang², Dicky Aligheri², Retno Dwi Astuti
}

\begin{abstract}
Latar Belakang : Trombosis vena dalam iliofemoral berhubungan dengan obstruksi aliran vena berat yang mengakibatkan gejala dan sekuele yang lebih berat. Pasien dengan kondisi ini memiliki risiko tinggi terjadinya sindrom pasca trombosis walaupun sudah mendapat terapi antikoagulan. Studi terkini menunjukkan bahwa terapi trombolisis dengan bantuan kateter memberikan manfaat dalam mengurangi sindrom pasca trombosis dan menjaga patensi vena. Beberapa randomized controlled trials besar sedang berjalan dan diharapkan dapat mengevaluasi keamanan dan efikasi tatalaksana ini pada pasien dengan trombosis vena dalam iliofemoral, dan juga menjelaskan siapa saja yang paling mendapat manfaat.

Ilustrasi Kasus : Seorang laki-laki 59 tahun datang dengan keluhan baal, nyeri, dan sulit menggerakan tungkai kiri yang didahului dengan kaki bengkak. Edema perifer ditemukan pada kedua tungkai pasien namun lebih berat pada tungkai kiri. Duplex sonografi menunjukkan trombus yang ekstensif dari vena iliaka hingga tibialis kiri. Terapi antikoagulan saja tidak memberi efek terhadap trombus. Trombolisis dengan bantuan kateter dilakukan dan memberikan perbaikan gejala dan pengurangan trombus yang bermakna.

Kesimpulan : Dilaporkan sebuah kasus trombosis vena dalam iliofemoral. Strategi tatalaksana terkini dengan antikoagulan tidak terbukti dalam hal mencegah sindrom pasca trombosis. Trombolisis dengan bantuan kateter adalah cara yang efektif dalam mencapai lisis bekuan darah pada trombosis akut, dan dapat membantu mencegah kejadian sindrom pasca trombosis. Potensi keuntungan dari terapi ini harus ditimbang baik-baik mengingat risiko perdarahan yang dapat terjadi. Saat ini terdapat beberapa randomized controlled trials besar yang sedang berjalan dan diharapkan dapat menyediakan basis bukti atas tatalaksana ini.
\end{abstract}

(J Kardiol Indones. 2014;35:285-95)

Kata Kunci: iliofemoral, trombosis vena dalam, trombolisis dengan kateter,sindrom pasca trombosis, antikoagulan

\section{Alamat Korespondensi}

Dr. Haris Munirwan, Departemen Kardiologi dan Kedokteran Vaskular, Fakultas Kedokteran Universitas Indonesia, Pusat Jantung Nasional Harapan Kita, Jakarta, Indonesia. E-mail: munirwanharis@ gmail.com
A

scending Stanford type A aortic dissection carries a high morbidity and mortality.Left untreated, it is a highly lethal event, where $40 \%$ of patients with dissection involving the ascending aorta die immediately, $70 \%$ within first $24 \mathrm{~h}, 94 \%$ within the first week, and 100\% within 5 weeks. ${ }^{1}$ Proper identification of the proximal origin 
of the dissection and determination of concomitant aortic valve involvement significantly facilitate surgical repair, which may improve survival. ${ }^{2}$ Rapid imaging is necessary for the timely diagnosis of a potentially lifethreatening condition.An ideal imaging modality will precisely, safely, and rapidly confirm suspected acute or chronic aortic pathology with quantitative information on aneurysm formation and progression, as well as on tear location, extent, and type of dissection, including evaluation for imminent complications.

With excellent accuracy and similar sensitivity and specificity, CT, MRI, and TEE have become diagnostic option. TEE is highly accurate for the detection of acute aortic syndromes especially identify ascending aortic pathology such as type A aortic dissection. ${ }^{3} \mathrm{We}$ report the unusual case of 52-year old male who present atypical presentation of aortic dissection with unclear view of dissection profile by Thorax CT Angiography aorta and diagnosed as Localized Stanford A Aortic dissection with supported data by echocardiography modality.

\section{Case Illustration}

A 52 year-old male referred from Surabayahospital with diagnosis Stanford type A Aortic dissection. Sixdays before admission to National Cardiac Centre Harapan Kita (NCCHK), he felt sudden choked neck when having sexual activitieswith less than 1 minute and gradually disappear at rest. No sweating, chest pain and dyspnea. There is no previous history of choked neck, chest pain or dyspnea. His coronary artery disease risk factor was smoker, hypertension, and dyslipidemia. Patient went to general hospital and diagnosed asUnstable angina pectoris.Echocardiography revealed normal ejection fraction, TAPSE $2.1 \mathrm{~cm}$ and found no regional wall abnormality. Patient alsounderwentCoronary CT scan and revealed normal coroner and found suspected intimal flap in aortic root. Patient then underwent CT Angiography AortarevealedIntimal flap near ostium Left anterior descendens (LAD) and Right Coronary artery (RCA) (Figure 1). The patient diagnosed asStanford type A Aortic dissection. The patient then referred to NCCHK for reevaluation and further management.

When admitted to NCCHK, the patient wasn't complaining any symptoms. Physical examination revealed blood pressure (BP) in Right arm 117/65

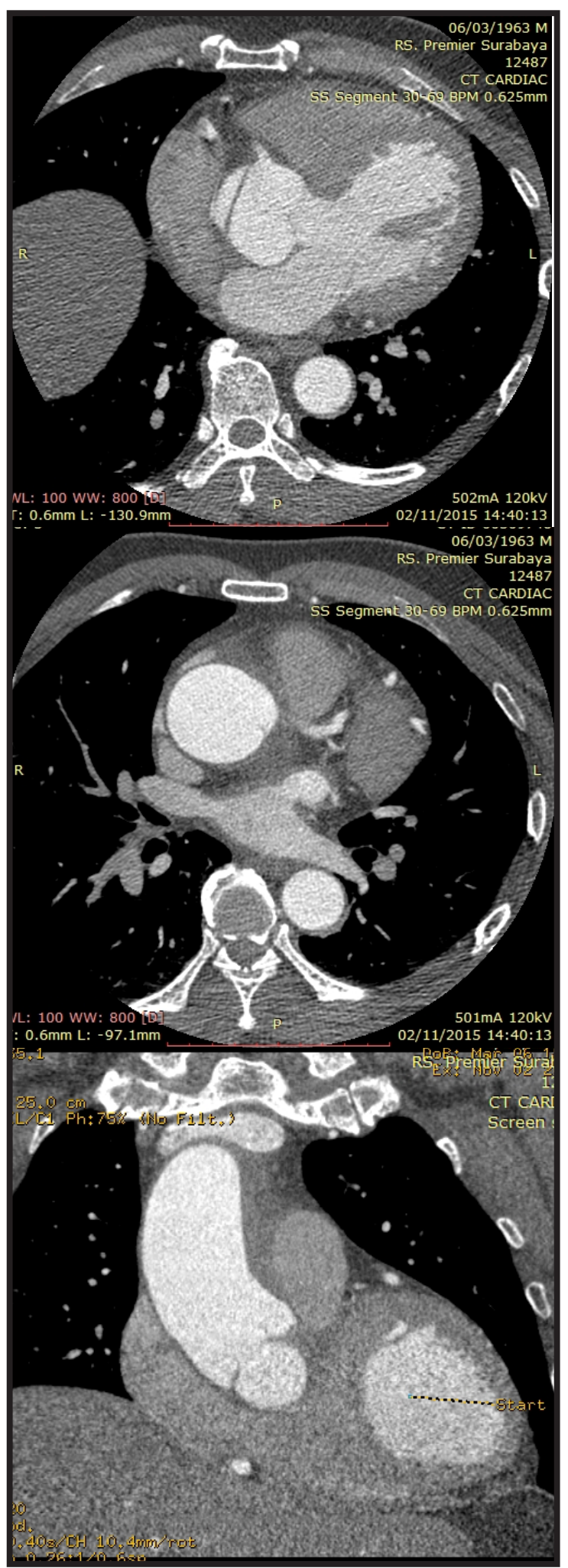

Figure 1. CTA Aorta: Normal coroner with suspected Intimal flap near ostium LAD and RCA 
mmhg, left arm 115/70 mmhg, right ankle 120/75 mmhg, left ankle $121 / 73 \mathrm{mmHg}$ and heart rate (HR) $65 \mathrm{bpm}$ and normal cardiac and lung examination. Electrocardiogram (ECG) revealed Sinus Rhythm, QRS rate $70 \mathrm{bpm}$, normoaxis, Normal P Wave, PR interval 0.16, QRS duration 0.08, no ST-T changes (Figure 2).

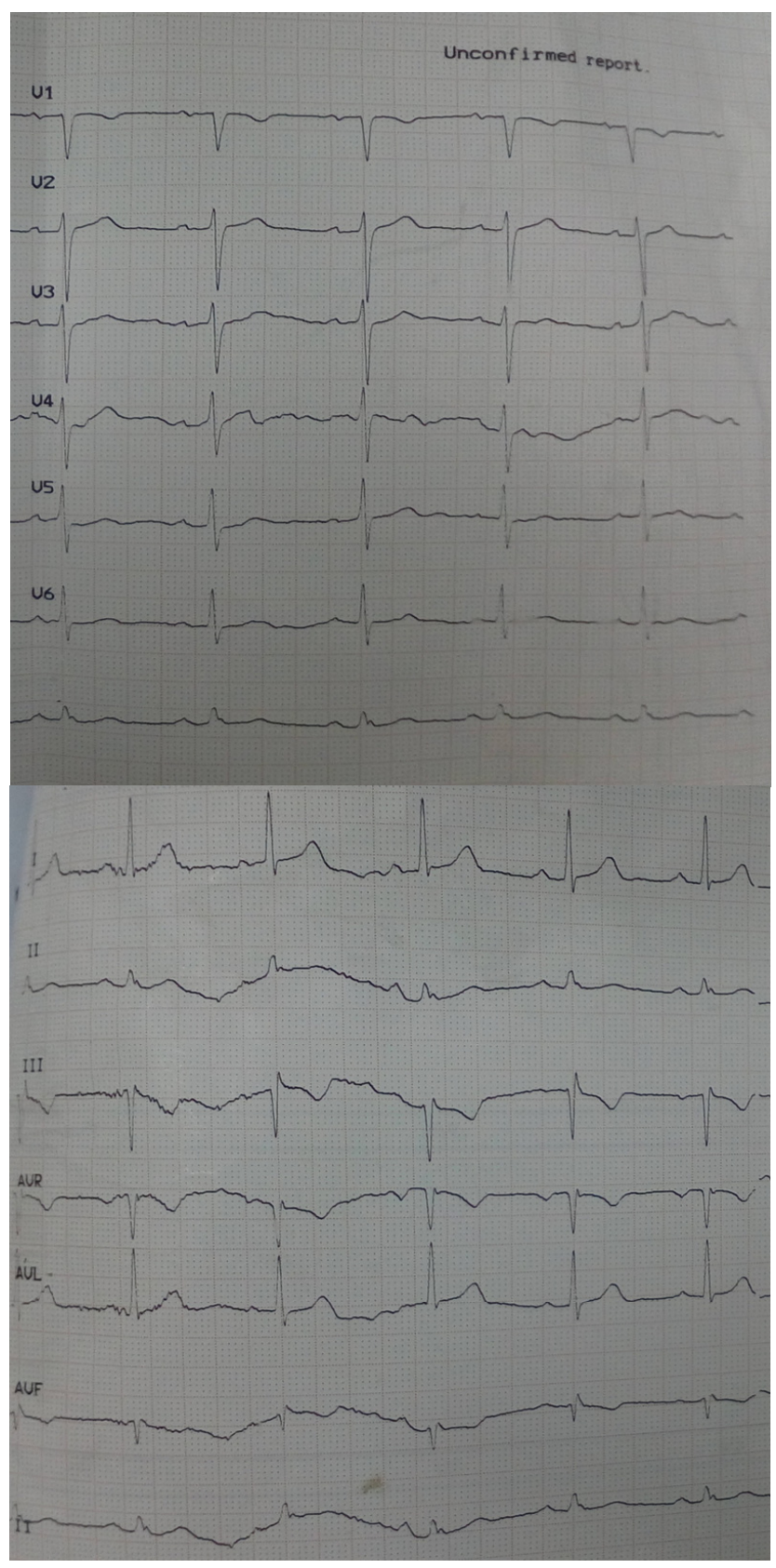

Figure 2. ECG revealed Sinus Rhythm, QRS rate 70 bpm, normoaxis, Normal P Wave, PR interval 0.16, QRS duration 0.08 , no ST-T changes
Chest x-ray (CXR) showed cardio-thoracic ratio of $60 \%$, aortic dilatation, normal pulmonary segment, normal cardiac waist, downward apex and no sign of congestion and infiltrate (Figure 3).

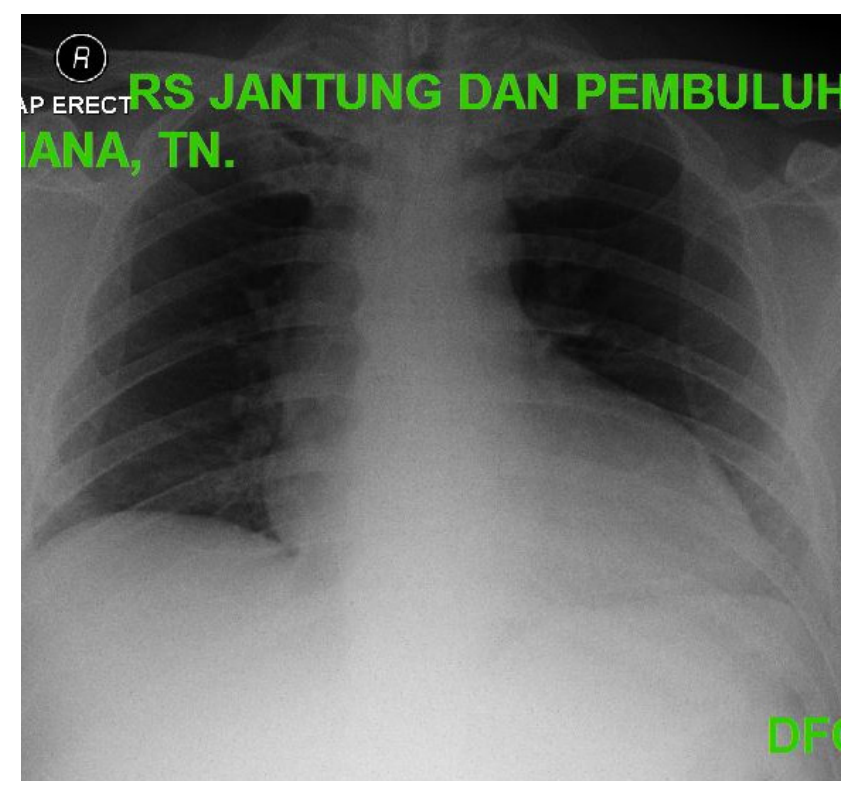

Figure 3. Chest x-ray revealed CTR 60\%, aortic dilatation, normal pulmonary segment, normal cardiac waist, downward apex, no sign of congestion and infiltrate.

Laboratory result at NCCHK showed hemoglobin 16 $\mathrm{g} / \mathrm{dL}$, hematocrit 44 vol\%, leucocyte 10720 cells $/ \mathrm{mm}^{3}$, thrombocyte 280000 cells $/ \mathrm{mm}^{3}$, Fibrinogen 612 , D-Dimer 1620 , ureum $28 \mathrm{mg} / \mathrm{dL}$, creatinine 1.24 $\mathrm{mg} / \mathrm{dL}$, random blood glucose $136 \mathrm{mg}$, sodium 135 $\mathrm{mmol} / \mathrm{L}$, potassium $3.3 \mathrm{mmol} / \mathrm{L}$, chloride $105 \mathrm{mmol} / \mathrm{L}$, Magnesium 2,26 mmol/L, total calcium 2,34 mmol/L. From serial evaluation, Hemoglobin decrease from 16 $\mathrm{gr} / \mathrm{dl}$ to $15.8 \mathrm{gr} / \mathrm{dl}$, no change in hematocrit, fibrinogen increases from 612 to 723 and D-Dimer decrease from 1620 to 1200 .

In second day, the case was discussed in Vascular team conference, and conclude that the findings from CT scan are not conclusive toestablishedconfident diagnosis of aortic dissection and proceed the patient to underwent emergent open-heart surgery,because there are possibilitiesthat the suspected intimal tear are normal valve of aortic root, artifact, or true dissection. The intimal tear was seen in only 2-segment level of axial view of CTA Aorta and there is no separated true and false lumen in coronal view.Furthermore, patient also complained no symptom and physical finding 
that wasn't support for aortic dissection Stanford Adiagnosis. In NCCHK, reevaluation from CTA Aorta also found not inconclusive view from CT angiography aorta (Figure 4).

The patient then underwentTTE in 9 November 2015 revealed dilatation of Sinotubular junction $(45 \mathrm{~mm})$ and aortic ascendens $(44 \mathrm{~mm})$ with intimal flap in aortic root (Figure 5).Based TTE, patient was underwent Transoesophageal Echocardiography (TEE)

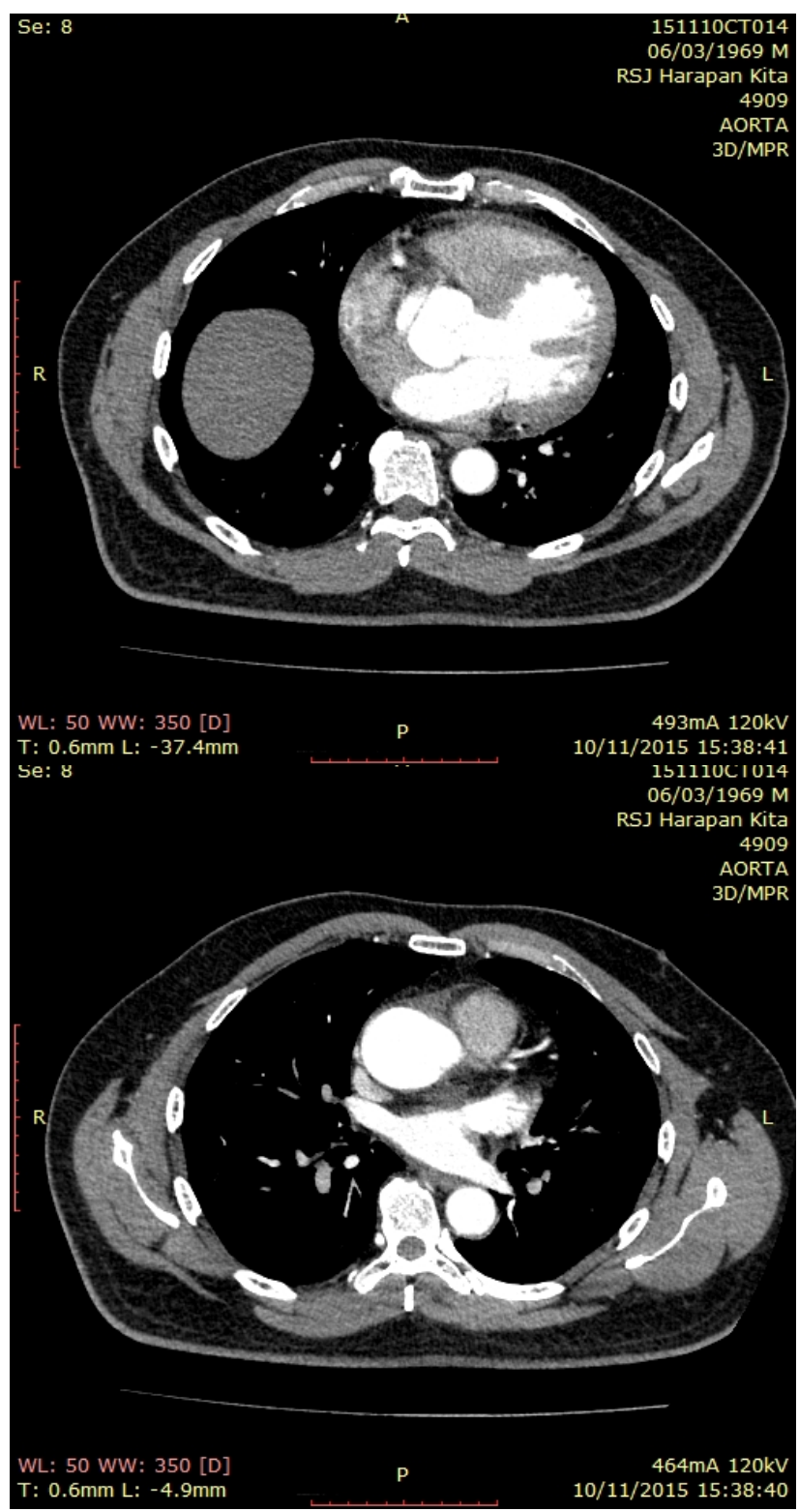

Figure 4. CT reevaluation in NCCHK: suspected Intimal flap near ostium LAD and RCA

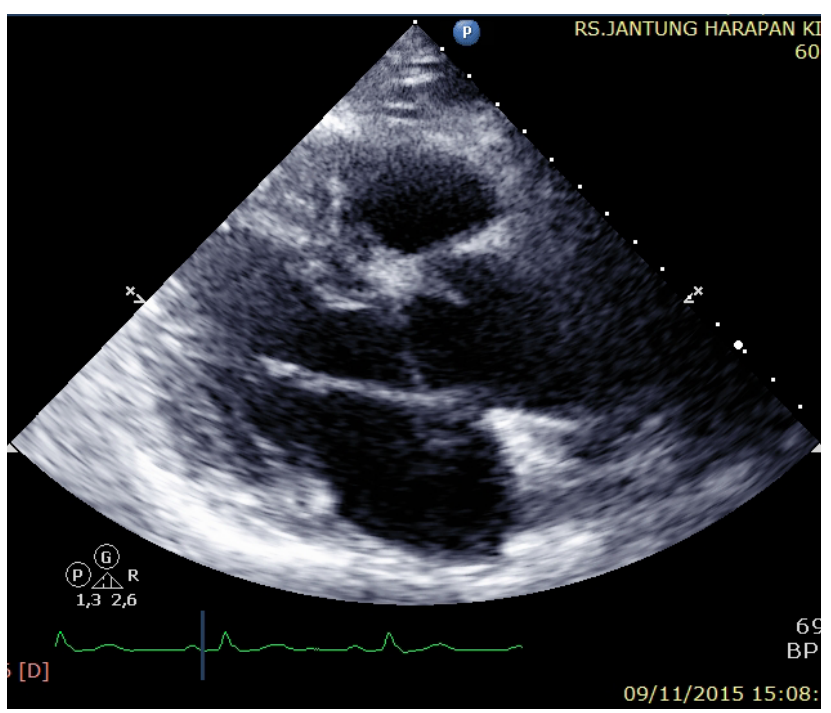

Figure 5. TTEin NCCHK; dilatation of Sinotubular junction $(45 \mathrm{~mm})$ and aortic ascendens $(44 \mathrm{~mm})$ with intimal flap in aortic root

to confirm the diagnosis. TEE revealed Localized Aortic ascendens dissection near ostium RCA (Figure 6). The patient was underwenturgent aortic ascending replacement, and found entry tear in distal aortic root between RCA and LCA ostium with localized dissection (Figure 6).After the operation, patient were hospitalized for 7 days and discharged with good condition.

\section{Discussion}

Acute aortic dissection is one of the most dramatic vascular events. ${ }^{4}$ Early mortality is $1.4 \% / \mathrm{h}$ within the first $48 \mathrm{~h}$ in non- treated patients. The incidence of aortic dissection has been estimated as $10-20$ patients/ year per 1 million inhabitants. ${ }^{5}$ Aortic dissection occurs when there is a disruption of the media and bleeding within and along the wall of the aorta occurs. It is characterized by the formation of a false lumen in the tunica media of the aortic wall. ${ }^{6}$ It's classified with Stanford, Be Bakey and New European Society of Cardiology classification..$^{7,8,9}$

Acute chest painis the most common symptoms. The classic characteristics of pain are its tearing or ripping quality, and, most of the time, pain is described as sharp or stabbing, but the description can be highly variable. Chest pain irradiating to the neck, throat, or 


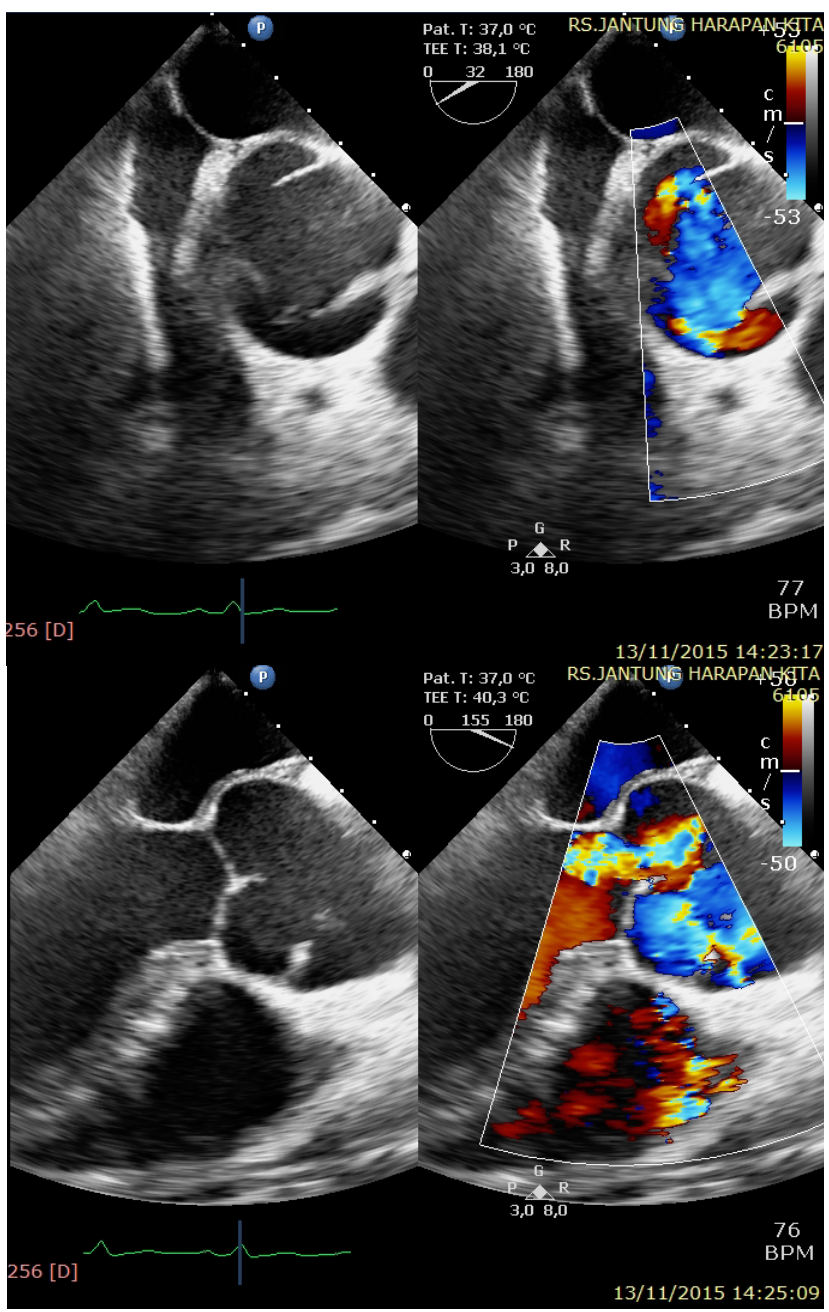

Figure 6. TEE: Localized Aortic ascendens dissection near ostium RCA A. Short axis view $32^{\circ}$ B. Long axis view $155^{\circ}$

jaw indicates that the aortic segment involved is the ascending aorta whereas pain located in the back or the abdomen suggests that the diseased segment is most probably the descending aorta ${ }^{10}$

The majority of patients with acute type A aortic dissection present with aortic diameters $<5.5 \mathrm{~cm}$. Although up to $75 \%$ of patients may be hypertensive, on presentation, $>50 \%$ patients with type A dissection may be found normotensive or hypotensive. ${ }^{11}$ Ischemic lower extremities $(30 \%)$ and tamponade $(5-10 \%$ in proximal dissections) may also be present. Paraplegia and other neurological signs may be present in up to $40 \%$ of patients. ${ }^{10}$

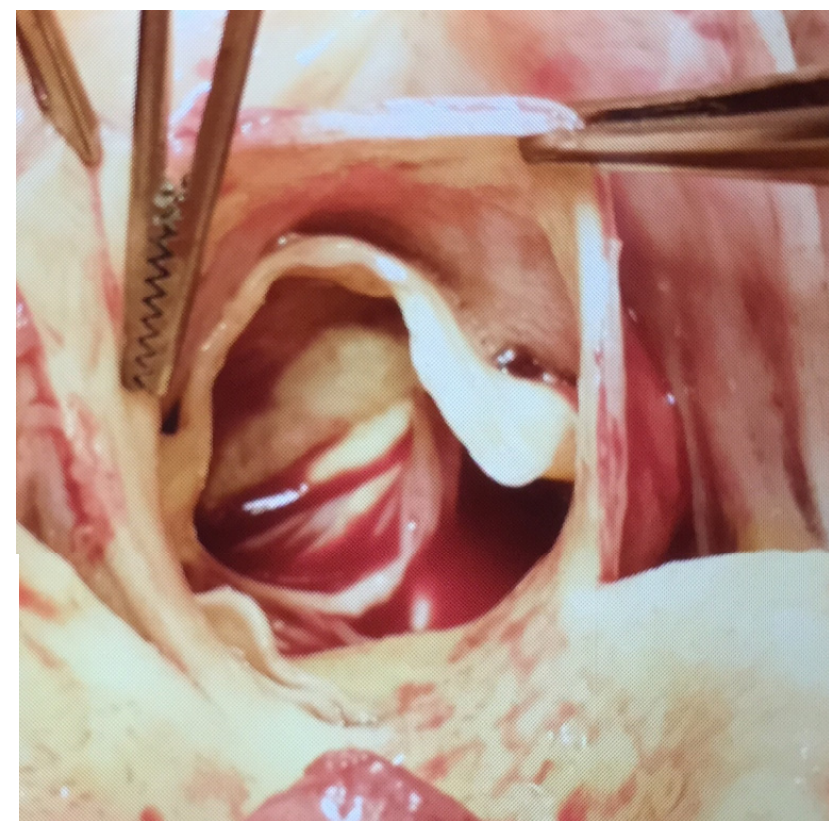

Figure 7. Surgical findings: dilatation from Sinotubular junction, localized dissection with entry tear in distal aortic root between RCA and LCA ostium

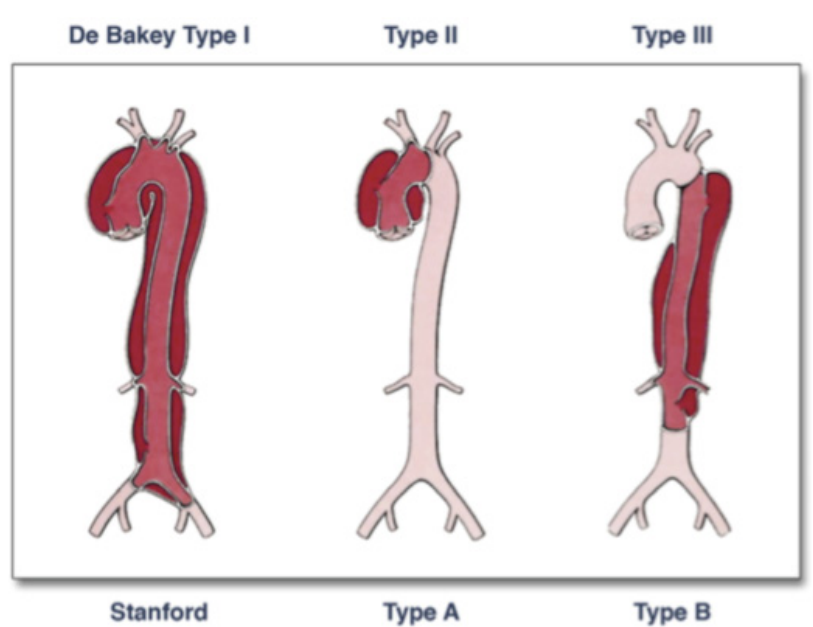

Figure 8. De Bakey and Stanford Classification of Aortic Dissection ${ }^{3}$

\section{Role of Echocardiography as Supporting Diagnostic Modality in Localized Stanford A Aortic dis section}

The management of acute type A aortic dissection continues to be a prime example of life-saving, emergent open-heart surgery. ${ }^{13}$ The diagnosis should 


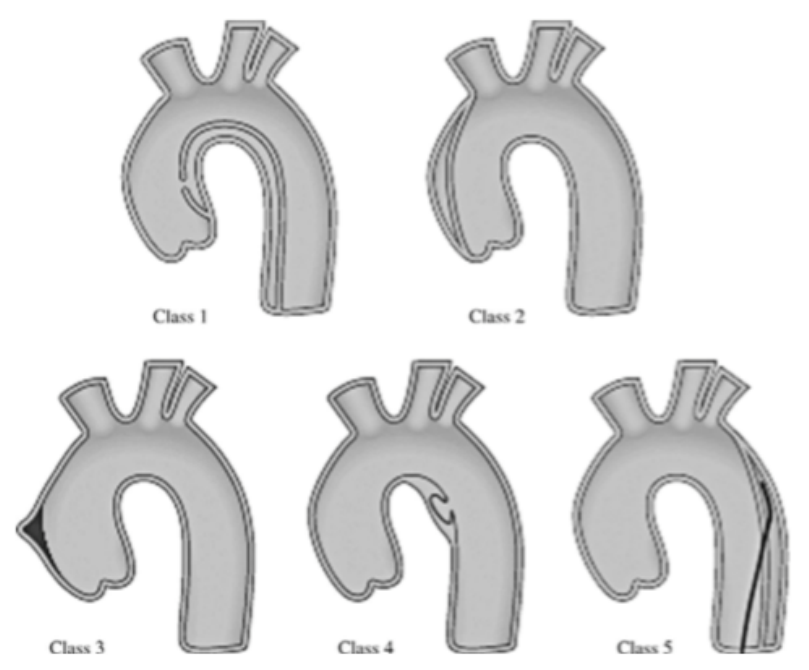

Figure 9. The new European Society of Cardiology Classification ${ }^{12}$

be clear before the patient underwent the life saving surgery. Localized Stanford type A aortic dissections are uncommon case with unknown prevalence and prognostic. Rapid and accurate diagnosis of aortic dissection are mandatory. ${ }^{14}$

Diagnosis accuracy of TEE, CT and MRI are similar and decision depends on availability and experience of the staff present. In most centers, CT is the first imaging technique, but during diagnosis work up, when there is a doubt in established the diagnosis, another imaging modality (mainly TEE) is needed ${ }^{14}$

\section{Transthoracic echocardiography}

TTE is very useful in identifying aortic valve dysfunction, pericardial tamponade, or wall motion abnormalities, and may screen for proximal 4 to $8 \mathrm{~mm}$ of the ascending aorta to just above the sinotubular junction in patients with good echocardiographic windows and a short segment of the descending aorta. It may show the intimal flap and a thickened aortic wall. The proximal ascending aorta can usually be seen in long- and short-axis parasternal views.

TTE is limited in visualizing the distal ascending aorta and the arch. The descending thoracic aorta appears as a circular structure behind the left atrium in the parasternal long-axis view and occasionally may be mistaken for a dilated coronary sinus. However, the more rigid shape of the aorta as well as the proximity of the coronary sinus to the atrioventricular groove should prevent this from happening. ${ }^{14}$

Echocardiographic diagnosis of aortic dissection is based on the detection of an intimal flap that divides the aorta into the true and false lumen. False lumen flow from true lumen may be detected by colour Doppler flow but sometimes in cases of thrombosis or retrograde dissection, colour flow is absent (Table 2). ${ }^{10}$

Table 2. Echocardiographic features of true and false lumen ${ }^{14}$

\begin{tabular}{lll}
\hline & False lumen & True lumen \\
\hline Size & Large & Small \\
\hline Pulsation & $\begin{array}{l}\text { No, systolic } \\
\text { compression }\end{array}$ & Yes \\
\hline Flow direction & $\begin{array}{l}\text { Systolic antegrade flow } \\
\text { reduced or absent, or } \\
\text { retrograde flow }\end{array}$ & Systolic antegrade flow \\
\hline Communication flow & $\begin{array}{l}\text { From true to false } \\
\text { lumen in systole }\end{array}$ & Absent \\
\hline Spontaneous contrast & Frequent & Thick \\
\hline Wall & Thin & No \\
\hline Thrombosis & Yes & \\
\hline
\end{tabular}

Proximal aortic dilation is usually seen in ascending aortic dissection. The presence of normal aortic dimensions and geometry and absence of aortic regurgitation on TTE are evidence against the presence of an ascending aortic dissection, but this does not fully exclude the diagnosis. Very occasionally, a dilated descending aorta may be visualized behind the atrioventricular groove in a parasternal long-axis view, and this may indicate the presence of dissection or aneurysm in the descending aorta (Figure 11).

The overall sensitivity of TTE in diagnosing all forms of aortic dissection is only $59 \%$ to $83 \%$ and specificity is $63 \%$ to $93 \%$ when compared with other modalities. For type A aortic dissection it has a sensitivity of $78 \%$ to $100 \%$, but for type B dissection its sensitivity is only $31 \%$ to $55 \%(6-8)$. A negative TTE, therefore, does not exclude aortic dissection. TTE has been considered of limited value in the diagnosis of aortic dissection. Due to its availability, rapid information, and capability of alternative and additional diagnosis, it is performed as the first-line imaging technique in the emergency department. ${ }^{3}$ Due to its low negative predictive value of TTEdoes not allow ruling out the diagnosis and further studies are needed. ${ }^{15}$

This patient came with non-specific symptom with 


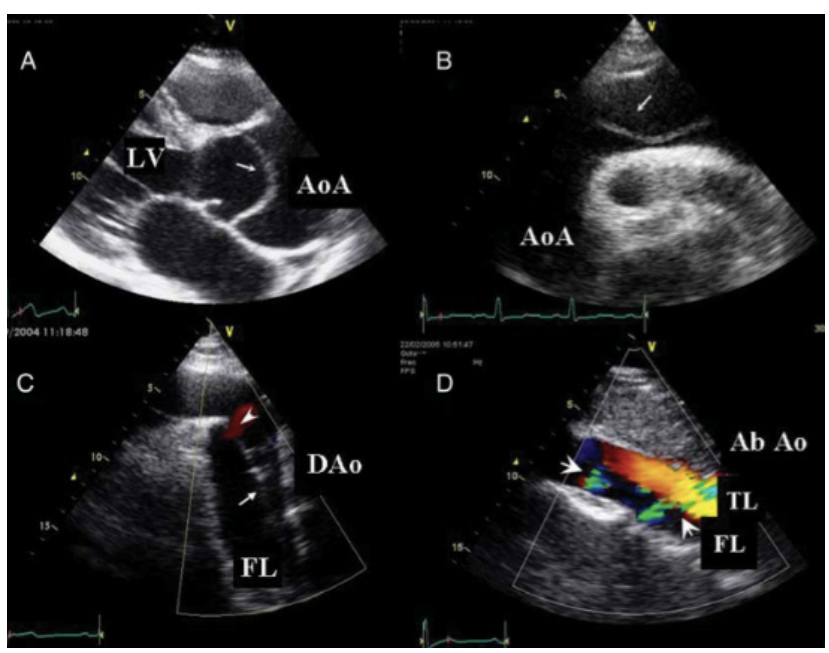

Figure 10. Aortic dissection diagnosis fromTTE. Intimal flap (arrows) and two lumina are visualized in: (A) aortic root, (B) aortic arch and distal ascending aorta, (C) proximal descending aorta (arrowhead shows the entry tear), and (D) dissection of abdominal aorta. Colour Doppler helps to identify the true lumen ${ }^{3}$

only choked neck when having sexual activities with less than one-minute duration and suddenly disappears at rest. When admitted to NCCHK, patientwasn't complaining any symptom and found normal physical findings. The diagnosis of Stanford A aortic dissection was made in previous hospital because intimal flap wasaccidentally discovered when patient underwent Coronary CT scan. Then the patient underwent CTA aorta and revealed suspected intimal flap in only two to three slice of CT at aortic root near RCA ostium in axial view, without separated true and false lumen in coronal view. Commonly, patient with Stanford A aortic dissection admitted to hospital with worse condition.

Recent series of type A aortic dissection report that at hospital arrival, $50 \%$ of patients are haemodynamically unstable, $25 \%$ have a neurologic deficit, $20 \%$ have tamponade, and $6 \%$ have required cardiopulmonary resuscitation. Hypotension complicating acute dissection may result from cardiac tamponade, acute aortic rupture, or heart failure related to acute severe aortic regurgitation. ${ }^{16}$

The physical findings most typically associated with ascending aortic dissection are pulse deficits, aortic regurgitation, and neurologic manifestations. Pulse deficit was reported in 19\% cases, aortic regurgitation in $41-76 \%$ case, and Neurologic manifestations occur in $17 \%$ to $40 \%$ cases include persistent or transient ischemic stroke, spinal cord ischemia, ischemic neuropathy, and hypoxic encephalopathy and are related to malperfusion of one or more branches supplying the brain, spinal cord, or peripheral nerves. ${ }^{17,18}$ But in this patient, we found no abnormal physical findings.

D-Dimer use is also limited. There is no data of D-Dimer in first 24 hours that very sensitive for aortic dissection if increase $>500 \mathrm{ng} / \mathrm{mL}$. CTA Aorta findings in common patient in Stanford type A aortic dissection is a partition between the true and false channels; such a partition, which is formed by the intimal flap and extend to aortic root or to aortic arch. But in this case, the intimal flap is only seen in two slice of CT at aortic root near RCA ostium.

A confident diagnosis of aortic dissection with CT was based on the detection of an intimal flap in the thoracic aorta that separated the true and false lumen. Several artifacts and pitfalls were encountered that could result in false-negative or false-positive diagnosis. These were attributable to $(a)$ technical factors, $(b)$ streak artifacts, $(c)$ periarotic structures (eg, aortic arch branches, mediastinal veins, pericardial recess, thymus, atelectasis, pleural thickening or effusion adjacent to the aorta) (d) aortic wall motion and normal aortic sinuses. Many of the artifacts that simulate aortic dissection are suspected due to lack of deformity of the aortic lumen. ${ }^{19}$ Other possibility are valvefrom aortic cuspis that mimicking dissection. This is the reason why the surgical conference needs another modality to make sure the aortic dissection diagnosis.

Echocardiography in NCCHK revealed dilatation of Sinotubular junction $(45 \mathrm{~mm})$ and aortic ascendens $(44 \mathrm{~mm})$ with intimal flap in aortic root. The intimal flap was seen from PLAX view. This finding was increased the suspicion of aortic dissection. The overall sensitivity of TTE in diagnosing all forms of aortic dissection is only $59 \%$ to $83 \%$ and specificity is $63 \%$ to $93 \%$ compared with other modalities. A negative TTE, therefore, does not exclude aortic dissection. So TTE is not the modality of choice to established aortic dissection diagnosis but as supporting diagnostic modality. ${ }^{3}$ The patient then underwent TEE to confirm the diagnosis based on the algorithm (Figure 13).

\section{Transoesophageal echocardiography}

Proximity of the esophagus and the thoracic aorta permits high-resolution images from higher-frequency 


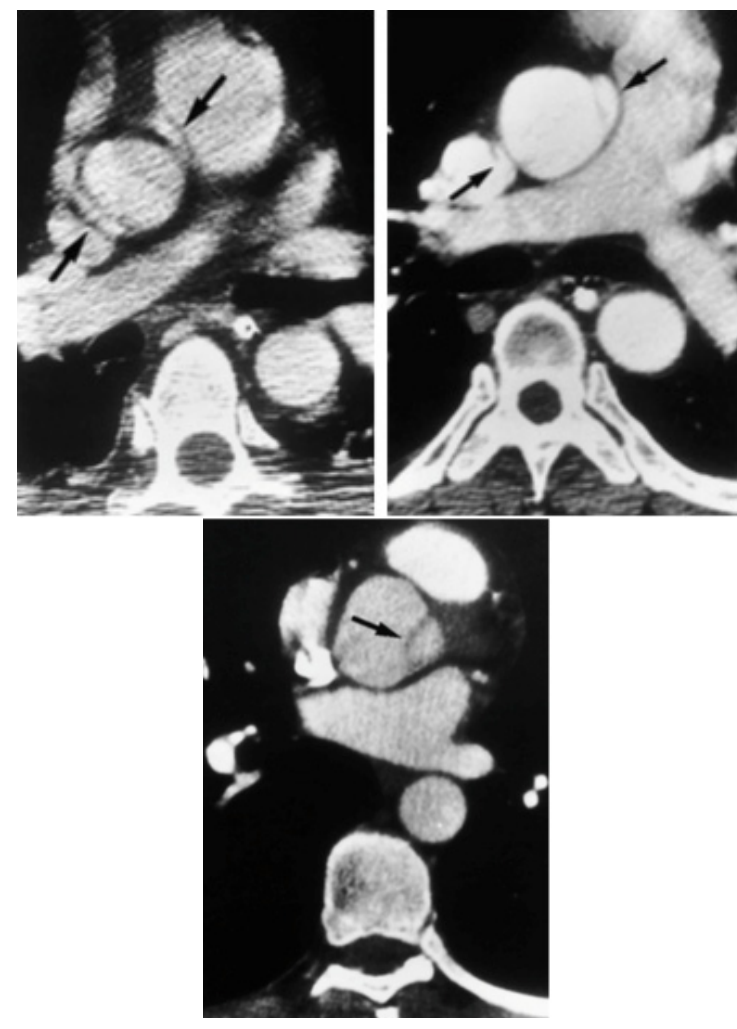

Figure 11. A. Streak artifact caused by suboptimal arm positioning. The patient was unable to elevate his arms and was scanned with his arms at his sides. Beam hardening caused by the arms produced the numerous artifacts seen along the posterior thorax. B. Motion artifact simulating aortic dissection C. Aortic valve cusps simulating intimal flaps. CT scan shows a curvilinear area of low attenuation along the left lateral aspect of the aortic root simulating an intimal flap (arrow). ${ }^{19}$
TEE. The availability of multiplane imaging permits improved incremental assessment of the aorta from its root to the descending aorta. The most important TEE views of the ascending aorta, aortic root and aortic valve are the high transoesophageal long-axis $\left(\right.$ at $\left.120^{\circ}-150^{\circ}\right)($ Figure $3 \mathrm{~A})$ and short-axis $\left(\right.$ at $\left.30^{\circ}-60^{\circ}\right)$ views. ${ }^{14}$

A short segment of the distal ascending aorta, just before the innominate artery, remains unvisualized owing to interposition of the right bronchus and trachea (blind spot). Images of the ascending aorta often contain artefacts due to reverberations from the posterior wall of the ascending aorta or the posterior wall of the right pulmonary artery, presenting as aortic intraluminal linear horizontal lines moving in parallel with the reverberating structures, as can be ascertained on M-mode tracings. The descending aorta is easily visualized in short-axis $\left(0^{\circ}\right)$ and long-axis $\left(90^{\circ}\right)$. Further withdrawal of the probe shows the aortic arch, where the inner curvature and anterior arch wall are usually well seen all the way to the ascending aorta.

Several studies have demonstrated the accuracy of TEE in the diagnosis of aortic dissection with sensitivity of $86-100 \%$, specificity $90-100 \%$, and NPV $86-100 \%$. The main diagnostic clue that TEE can provide in a patient with an aortic dissection is afinding ofintimal dissection flaps. M-mode ultrasound allows the detection and differentiation of intimal flaps in the aorta; enlargement of the aortic wall, dilation of the aortic root and enlarging of the posterior wall is possible; $\mathrm{M}$-mode ultrasound has also been described as useful for differentiating between real flaps and artifacts. ${ }^{20}$

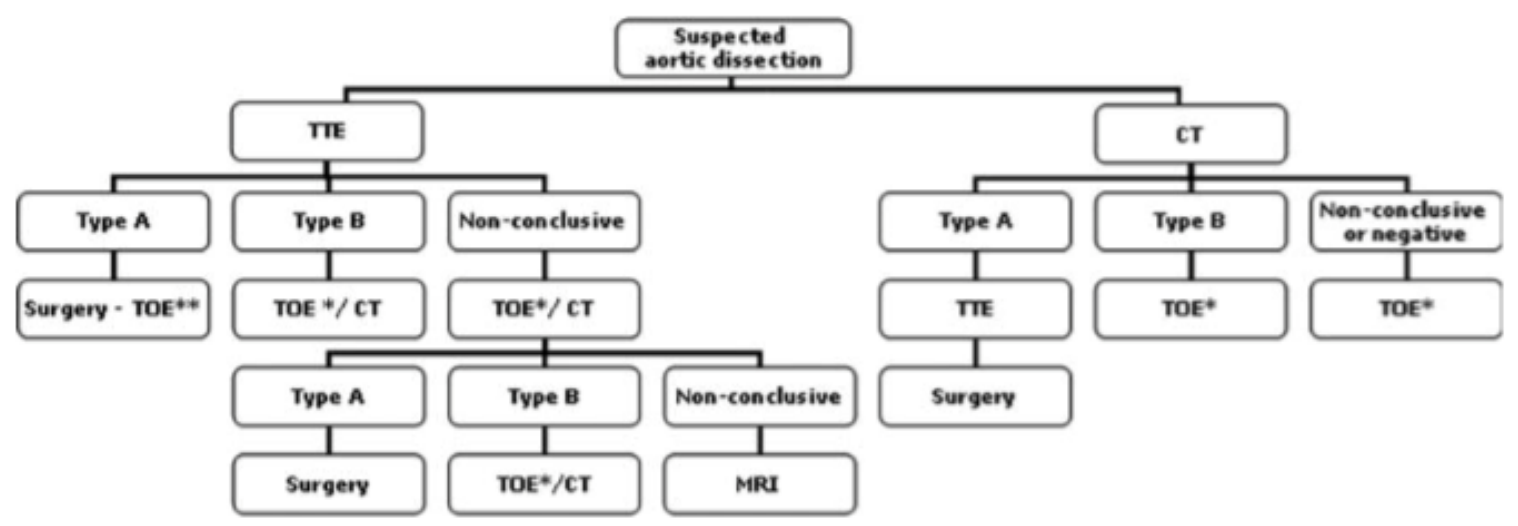

Figure 12. Algorithm of diagnostic strategy of acute aortic dissection depending on whether the first test was TTE or $\mathrm{CT}^{14}$ 


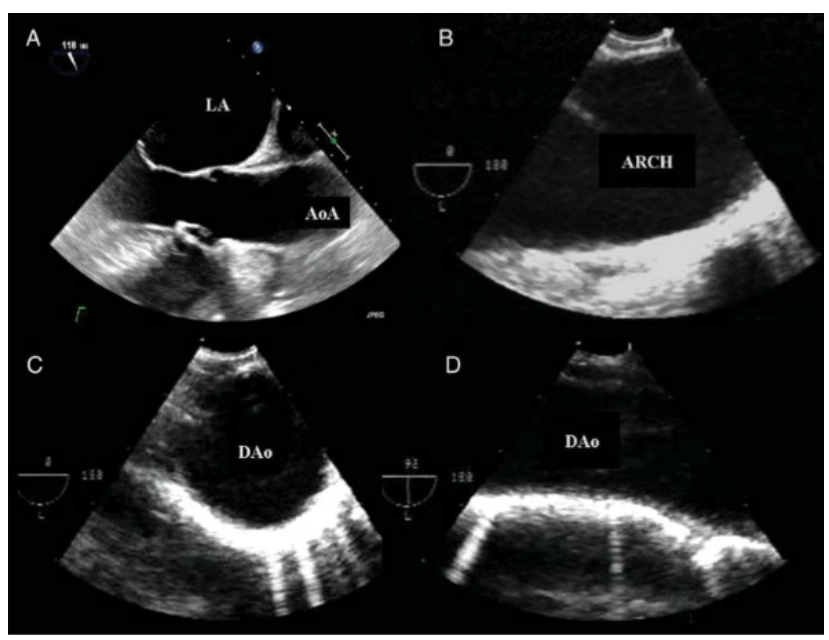

Figure 13. TEE. (A) Ascending aorta in long-axis view at $120^{\circ}$. (B) Aortic arch in transverse view. (C) Descending aorta visualized by transverse view. (D) Descending aorta visualized by longitudinal view. ${ }^{14}$

Major advantages of TEE include its portability (allowing for bedside patient evaluation), rapid imaging time, and lack of intravenous contrast or ionizing radiation. Additionally, dissection-related cardiac complications can be evaluated including aortic regurgitation, proximal coronary artery involvement, and the presence of tamponade physiology. When therapeutic decision-making is definitive by other techniques, TEE should be performed in the operating theatre before surgery or when the patient is haemodynamically stable with no chest pain. ${ }^{14}$

Several limitations of TEE need to be emphasized. First, it has limited ability to visualize the distal ascending aorta and proximal arch because of interposition of the air-filled trachea and the main bronchus. Second, the frequent appearance of reverberation artifacts may mimic a dissection flap, appearing as a mobile linear echo density overlying the aortic lumen.Third, TEE is less suited than CT and MRI for long-term serial imaging to monitor patients after an acute aortic syndrome. ${ }^{3}$

In figure 13, it's described the algorithm of diagnostic strategy of acute aortic dissection depending on the first test of imaging modality. In our patient, CT was done as first diagnostic modality to establish the diagnosis. CT revealed non-conclusive condition, than the patient underwent TEE to confirm diagnosis. TEE revealed Localized Aortic ascendens dissection near ostium RCA. In this patient, intimal flap was clearly seen in short axis $30^{\circ}$. False lumen identified by com- munication flow from true to false lumen in systole. In long axis $155^{\circ}$ view, intimal flap was seen just below non-coronary cuspis (NCC) of aortic valve.Confident diagnosis of aortic dissection was made and patient underwent urgent aortic ascendens replacement. From surgical findings, revealed dilatation from Sinotubular junction, localized dissection with entry tear in distal aortic root between RCA and LCA ostium. In patient with suspected aortic dissection, confident diagnosis is very important, because it will decided the further for the patient.

\section{Summary}

A 52 year-old male referred from Surabaya Premier hospital with diagnosis suspected Standford type A Aortic dissection. From evaluation in NCCHK, patient came with atypical presentation of aortic dissection, normal physical findings, and unclear profile of dissection in Thorax CT. Then patient underwent TTE and found intimal flap in ascending aorta. Due to low sensitivity and specificity of TTE to established the diagnosis of aortic dissection, patient underwent TEE and revealed Localized Aortic ascendens dissection near ostium RCA. Surgical findings found dilatation from Sinotubular junction, localized dissection with entry tear in distal aortic root between RCA and Left Coronary Artery (LCA) ostium and patient underwent aortic ascendens replacement surgery.

\section{References}

1. Col L, Menon A, Garg BAA, et al. Management of acute Type A aortic dissection. mjafi. 2013;(Mil):5-7.

2. Goldman ME, Guarino T, Mindich BP. Localization of Aortic Dissection Intimal Flap by Intraoperative Two-Dimensional Echocardiography. J Am Coll Cardiol. 1985;6(5):1155-1159.

3. Baliga RR, Nienaber CA, Bossone E. The Role of Imaging in Aortic Dissection. JACC. 2014;7(4).

4. Erbel R, Engberding R, Daniel W, Roelandt J, Visser C, Rennollet $\mathrm{H}$. Echocardiography in diagnosis of aortic dissection. Lancet (London, England). 1989;1(8636):457-461.

5. Meszaros I, Morocz J, Szlavi J, et al. Epidemiology and clinicopathology of aortic dissection. Chest. 2000;117(5):1271-1278.

6. Crawford ES, Svensson LG, Coselli JS, Safi HJ, Hess KR. Surgical treatment of aneurysm and/or dissection of the ascending aorta, transverse aortic arch, and ascending aorta and transverse aortic arch. Factors influencing survival in 717 patients. J Thorac 
Cardiovasc Surg. 1989;98(5 Pt 1):654-659.

7. DeBakey ME, McCollum CH, Crawford ES, et al. Dissection and dissecting aneurysms of the aorta: twenty-year follow-up of five hundred twenty-seven patients treated surgically. Surgery. 1982;92(6):1118-1134.

8. Fernández-Golfín C, Zamorano JL. Role of echocardiography. In: ESC Textbook of Cardiovascular Imaging. Vol 2nd ed. Oxford: Oxford University press; 2014:606.

9. Roberts CS, Roberts WC. Dissection of the aorta associated with congenital malformation of the aortic valve. J Am Coll Cardiol. 1991;17(3):712-716.

10. Katritsis DG, Gersh BJ, Camm AJ. Acute aortic syndromes. In: Clinical Cardiology, Current Practice Guidelines. Vol 1. ; 2015:1689-1699.

11. PG H, CA N, EM I, al et. The international registry of acute aortic dissection (irad): New insights into an old disease. JAMA. 2000;283(7):897-903.

12. Hebballi R, Fcarcsi F, Swanevelder J, Chb MB, Anes M, Sa FCA. Diagnosis and management of aortic dissection. 2009;9(1):1418.

13. Criado FJ. Aortic dissection: a 250-year perspective. Tex Heart Inst J. 2011;38(6):694-700.
14. Evangelista A, Flachskampf FA, Erbel R, et al. Echocardiography in aortic diseases : EAE recommendations for clinical practice. 2010:645-658.

15. Meredith EL, Masani ND. Echocardiography in the emergency assessment of acute aortic syndromes. Eur J Echocardiogr. 2009;10(1):i31-i39.

16. Kruger T, Conzelmann LO, Bonser RS, et al. Acute aortic dissection type A. Br J Surg. 2012;99(10):1331-1344.

17. Gaul C, Dietrich W, Erbguth FJ. Neurological symptoms in aortic dissection: a challenge for neurologists. Cerebrovasc Dis. 2008;26(1):1-8

18. Hiratzka LF, Bakris GL, Beckman J a, et al. 2010 ACCF/AHA Guidelines for the diagnosis and management of patients with thoracic aortic disease. A Report of the American College of Cardiology Foundation/AHA Task Force on Practice Guidelines, A. J Am Coll Cardiol. 2010;55(14):e27-e129.

19. Batra P, Bigoni B, Manning J, et al. Pitfalls in the diagnosis of thoracic aortic dissection at CT angiography. Radiographics. 2000;20(2):309-320.

20. Gonzalez-alujas T. Diagnosis of Ascending Aortic Dissection by Transesophageal Echocardiography : Utility of M-Mode in Recognizing Artifacts. 1996;27(1):102-107. 